\title{
Integration of hydraulic infrastructure in metropolitan São Paulo. Prospects of change in a context of growing vulnerability
}

\section{Ricardo Toledo Silva, São Paulo}

\section{Introduction}

Integration is a central keyword in contemporary water resources planning and management, particularly when urban areas are concerned. Integrated urban water management aims at controlling the interference of urban systems on the natural water cycle (BARTon et al. 2009; HeAney et al. 1999; LAwrence 2001). Quality and quantity are inextricably linked in urban water management (DAI et al. 2001; HEANEY et al. 1999), since water supply, sewage treatment, flood control and urban drainage infrastructures rely upon the same urban water cycles and embrace common environmental goals by means of multi-purpose infrastructures (O'ConNor et al. 2010). Interconnecting networks by and large exceed the territorial boundaries of municipalities and metropolitan areas, giving rise to complex challenges for cross-scale management (Braga et al. 2006; Silva 2000; ZevenberGen et al. 2008). Metropolitan integration involves advanced cross-sector management apart from water users, such as housing, urban transport and non-hydraulic energy sources, due to their central role on urban structuring (Braga et al. 2006; Silva \& Porto 2003; The World BANK 2004).

Flood control and urban drainage are, today, the segments of hydraulic infrastructure recurrently associated to instant natural disasters and to urban resilience (Arisz \& Burrell 2009; ZevenberGen et al. 2008). Instant water supply cross-contamination may also be due to floods, when stormwater enters treated water reservoirs, in possible association with wastewater, due to failure of sewer hydraulic seals. Sequential collapsing processes involving different infrastructure modes have been approached as cascading failures (LINDLEY \& Singpurwalla 2002; Little 2010). Water security faces more than instant disasters and cascading failures related to floods; it includes multiple threats of contamination or depletion vis-à-vis fresh water sources and urban access to drinking water, either focused on human-induced events and disaster mitigation strategies (Sharan et al. 2007) or on a holistic view of sustainable access, on a watershed basis (NoRMAN et al. 2010). The notion of water security in this article, albeit not directly focussed on water supply, is dealt with within a broader and persistent process of water governance. Regulatory and managerial fragmenta- tion of networks has hampered the prospects of integration and contributed to infrastructure vulnerability and disruption (Graham 2010). To a large extent this is due to the market logic applied to each service even though full privatization in Brazil is not an issue as it is in the United Kindom and other European countries (Guy et al. 1997; Graham \& Marvin 2001; Helm \& TINDALl 2009). In Brazil, utilities like telecommunications and electricity have more direct private participation than water supply, sanitation or urban drainage. In spite of that, the latter have been adapted to welcome different forms of private investment and mixed management, under a regulatory reform comparable to fully privatized contexts (SILva 2000).

By and large, the areas of low infrastructure coverage and connectivity are those which are environmentally fragile, located in the outskirts of the main urban concentrations; and the groups more likely to directly suffer from an uneven access to networked services are those living in the poor settlements developed there. When an unexpected event occurs, be it a flood, a land slide or a severe drought limiting water distribution, the main victims are generally the poor population living in these precarious areas (MARTINE 2008; Silva 2000).

Three metropolitan initiatives discussed below show that infrastructure robustness and safety, both in face of chronic vulnerability and disaster resilience, are more a question of the joint performance of associated functions than of the single functioning of each service.

\section{Integration and fragmentation in the São Paulo hydraulic infrastructure}

The sources of the Tiete river, located in the western slope of the coastal mountains chain, flow westwards to the continental plateau instead of eastwards to the sea. This implies limited water availability, despite a relatively high local rainfall of around $1,440 \mathrm{~mm} /$ year. The $5,985 \mathrm{~km}^{2}$ area of the basin, encompassing 35 of the 39 metropolitan municipalities, is part of a larger metropolitan area of $8,051 \mathrm{~km}^{2}$. Around 20 million people lived in this area in 2010 . Approximately $54 \%$ of the metropolitan surface or $4,356 \mathrm{~km}^{2}$ has been considered as water catchment areas and as such, legally protected.

As may be seen in Fig. 1, the six reservoirs from right to left, located east of the basin, yield approximately 


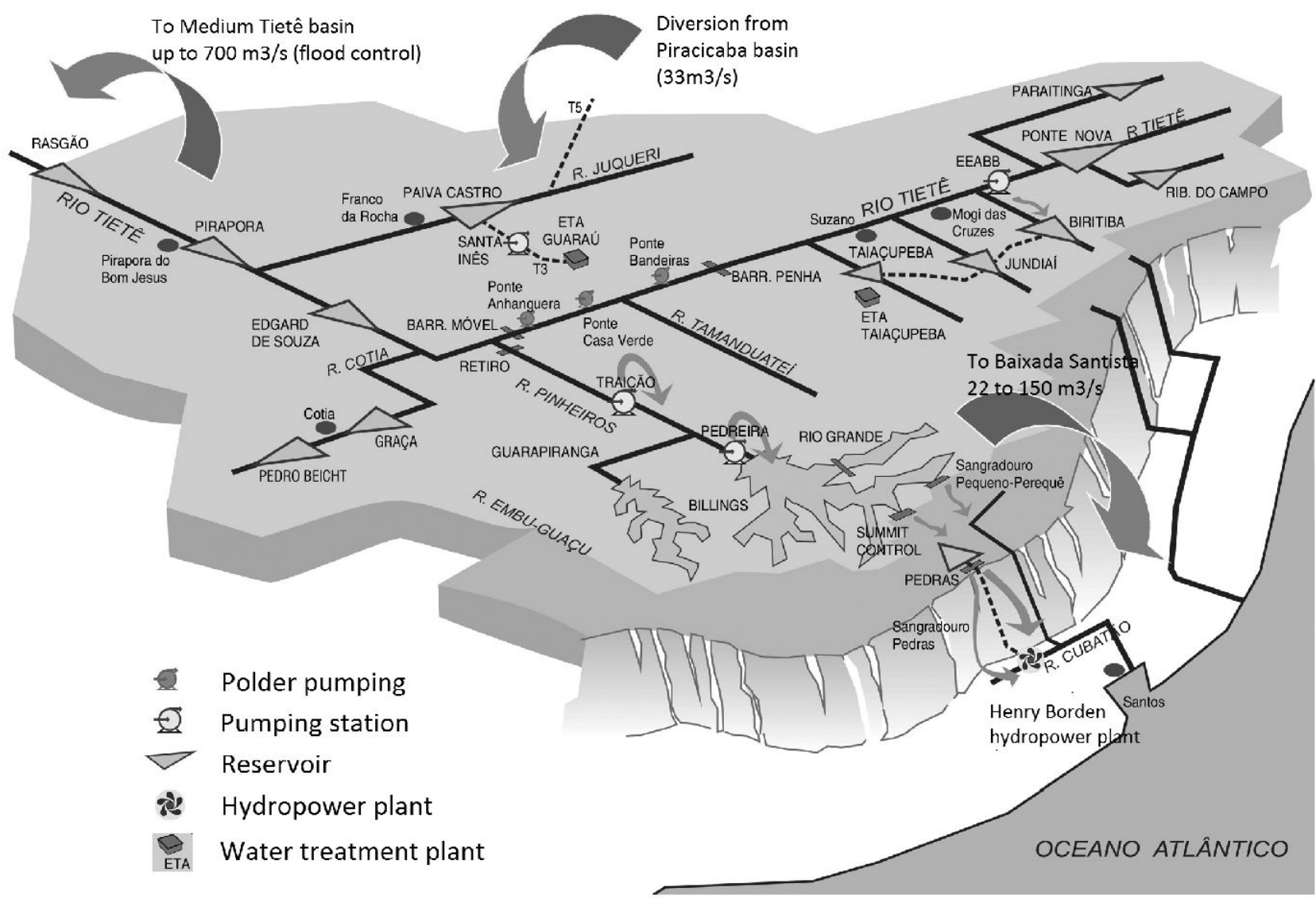

Fig. 1: Isometric scheme of Upper Tietê river basin operation

Schéma isométrique de l'opération des bassins hydrographiques de la Haute-Tietê Isometrisches Schema der Infrastruktur für das Flusseinzugsgebiet des Oberen Tietê Source: São PAUlo 2010

$14 \mathrm{~m}^{3} / \mathrm{s}$. They function also as flood control buffers in the meandered natural upstream river of the eastern part of metropolitan area. This part of the river is critical for flood control since the meandered riverbanks and adjacent permeable sites delay and reduce peak storm flows before they enter the metropolitan center.

The end of the central segment is limited by a mobile dam south of the confluence of the Pinheiros river, the most complex branch of the metropolitan hydraulic infrastructure. Originally a tributary to the Tietê river, the Pinheiros river had its course reversed in the early 1940 's to fill up Billings reservoir to the extreme south of the metropolis, at the upper edge of the coastal mountains. The reservoir was built to run a hydropower plant in the foothills $720 \mathrm{~m}$ below. By the end of the 1930's, the existing Guarapiranga reservoir, also in the southern Pinheiros river upstream, was transformed from a flow stabilization facility into a major water supply source. At that time, the Traição pumping station started to operate in the Pinheiros river, elevating its inverted flow by $5 \mathrm{~m}$, followed by a second station, Pedreira, elevating it $25 \mathrm{~m}$ higher to the entrance of the new reservoir.

During the 1970 's, a $31 \mathrm{~m}^{3} / \mathrm{s}$ diversion was completed from the neighboring basin, Piracicaba, leading to strong regional dispute as that region is also characterized by intense economic activity. The water supplied for urban use was to return to the main Tietê channel - and to the inverted Pinheiros flow - as wastewater. In principle such a solution would not aggravate the water quality in the basin, should wastewaters be treated before disposal. However, the metropolitan treatment system simultaneously planned was systematically delayed, and this implied growing pollution.

The institutional structure of the Brazilian System of Water Resources Management was deeply changed during the 1990's (Pagnoccheschi 2000). A wide par- 
ticipatory system of basin committees replaced the preceding hydropower hegemony. In São Paulo, new prospects for integration, taking the specific water conflicts of this densely urbanized area into consideration, where developed by researchers of the University of São Paulo in collaboration with the State Council of Water Resources and proposed in the Alto Tie tê River Basin Plan (Fundação de Apoio À Universidade DE SÃo PAUlo - FUSP 2002). Conceptually, four levels of integration were considered: (i) integration between systems/activities directly related to water use in the river basin area; (ii) territorial and jurisdictional integration with urban planning and management; (iii) regulatory cooperation with sectoral systems that are not direct users of the water resources, such as housing and urban transport; (iv) communication with the neighboring basins, in order to establish stable agreements on the current and future conditions of flows and export of water used in the basin (BRAGA et al. 2006; Silva \& PoRTo 2003). The latter gave rise to the formulation of principles of macro-metropolitan integrated management, discussed below. The plan went further than proposing specific interventions, it aimed at integrating sectoral initiatives under a wide territorial and functional prospect.

\section{Metropolitan initiatives in a fragmented environment}

\subsection{Metropolitan Initiative 1: preserving the water catchment}

The Guarapiranga project, launched in the early 1990 's, consisted of five main subcomponents as well as project management (The WorLD BANK 2004): (i) water supply and sewerage works; (ii) municipal solid waste collection and disposal; (iii) urban upgrading/rehabilitation; (iv) environmental protection; and (v) river basin management. The actions implemented in these components aimed at reducing between $33-45 \%$ of the phosphorus loads discharge into the reservoir, seriously threatened by an accelerated pollution process.

To link land use and final targets on water de-pollution, a mathematical model was developed, correlating different standards of land use with pollution load (OLIVEIRA DE Jesus 2006). Target loads were then established based on the maximum admissible discharge for each tributary and branch of the reservoir. These correlations have recently been integrated into Guarapiranga specific state law (SÃo PAULo 2006), leading to guidelines being fixed to reduce the nominal load discharge to $147 \mathrm{~kg}$ of phosphorus per day. These guidelines address land use control and regulation, urban and environmental upgrading, implementation and operation of sanitation infrastructure, direct water treatment on receiving water bodies, and the delimitation of special protection areas, specifically dedicated to water production.
Direct results of this project included nearly 40,200 households being connected to a sewer system and about 15,700 families benefiting from slum upgrading, while another 4,500 were relocated. The original Guarapiranga project developed into an extensive program of integrated management in the water catchment areas. Although focused currently on the surrounding areas of Billings reservoir, there are plans to extend the program to other metropolitan headwaters (Araúso et al. 2009).

Despite claims of environmental organizations about material results remaining limited (WHATELY et al. 2008), the main achievement of the Guarapiranga project is the formalization of the correlation model as a stable criterion to evaluate the impacts of urban occupation on surface waters. It has since been used in other projects with similar conditions and as an evaluative tool in assessing the impact of hydraulic infrastructure alternatives.

\subsection{Metropolitan Initiative 2: flood control strategy}

The severe floods of 2009 in São Paulo confirmed observations made during the last decade by the state water operators regarding changing patterns of seasonality and continuity of rainy events (SÃo PAUlo 2009a). Hydrologic evaluation of the 2009/10 heavy floods showed peak precipitations that were not unusual for the rainy season (BARros 2010). The decisive factor leading to durable inundation and extensive land sliding was the saturation of detention capacities after recurrent rainy events during the dry season, and an unprecedented continuity of more than 40 days of heavy rain in the wet season.

Detention capacities were hindered both in the areas remaining permeable within the urban tissue and in the detention ponds operating at each drainage compartment. The former was mainly due to the soaking of the surface and subsurface soil strata since the dry season, and the latter due to the very short time span between sequential storms, too short to allow for a drainage of the full ponds. Consistent with the studies of Heaney et al. (1999) on rainfall-runoff relationships, flood events in São Paulo have shown that keeping permeable surfaces and detention capacities is of benefit particularly for moderate to medium rain depths.

Apart from the construction of new detention ponds and the development of linear parks to augment permeable surface areas, specific measures to improve real time operational control (SÃo PAULO 2009a) were imperative. They included upgrade of the monitoring system (meteorological radar and telemetric data collecting network), its interconnection with the civil defense alert networks, and the development of redun- 
dant electricity connections to electro-mechanical appliances for flood control. Among these measures, the most controversial is the improvement of the reverse flow pumping capacity on the Pinheiros river from 280 to $420 \mathrm{~m}^{3} / \mathrm{s}$, since it questions the prevailing regulatory and environmental controls so far applied to single infrastructure interventions.

\subsection{Metropolitan Initiative 3: depollution project in the southern metropolitan hydro-energetic complex}

The reversion of the Pinheiros river from its confluence to the Tietê river to fill Billings reservoir started in the early 1940 's. Primarily aimed at hydropower use, it also played a central role in controlling extensive and lengthy floods in its basin. In the dry season, the natural flow of Pinheiros basin is about $10 \mathrm{~m}^{3} / \mathrm{s}$, which is too low for hydropower demand in the Billings reservoir. For this reason, water from the main Tietê channel, which vary from 50 to $150 \mathrm{~m}^{3} / \mathrm{s}$ in seasonal average, were diverted. However, the diversion of water led to growing pollution as the coverage of sanitation remained behind population growth until the late 1980 's. In 1989 , a state constitutional provision proscribed the pumping of untreated water to Billings reservoir, which meant that the Pinheiros river reversion was kept only for flood control from 1992 onwards. As a consequence, electricity generation at the Henry Borden plant was reduced to about $20 \%$ of its capacity.

In the early 2000 's, the state government, by means of the state corporations Companhia de Saneamento Básico do Estado de São Paulo - SABESP (water supply), Empresa Metropolitana de Águas e Energia S.A. - EMAE (electricity generation) and Companhia de Tecnologia de Saneamento Ambiental - CETESB (environmental technology), in partnership with Petrobrás (the national oil corporation) built a prototype of a direct treatment system by flotation on the Pinheiros river main channel. It was initiated with depollution of the river in mind and resumption of dry season reversion. The treatment capacity of the prototype was limited to $10 \mathrm{~m}^{3} / \mathrm{s}$, which was about $20 \%$ of the design target for the final system.

Supported by stringent federal and state regulations and local environmental organizations, the state Public Prosecutors for Environment initiated a civil action against the state government and its agencies. It succeeded in stopping the prototype's operation a few weeks after its launch in 2001. After years of negotiation, a judicial settlement was established in 2007 to resume tests on the installed prototype, now including an exhaustive list of parameters to be monitored at selected points on the river and on the reservoir. Among several requirements, values for phosphorus and BOD5 concentrations after treat- ment, for example, were expected to be as low as $0.03 \mathrm{mg} / 1$ and $10 \mathrm{mg} / 1$, respectively. The system proved to be efficient on relative removal $-91 \%$ for phosphorus and $49 \%$ for BOD5 (FundaÇão CENTRo TECNOLÓGICO DE HIdRÁUliCA - FCTH 2009) - but did not match absolute compliance to «class 2 » water quality standards (Conselho Nacional de Meio Ambiente - CONAMA 2005), as was demanded in the lawsuit. This class implies compliance for urban water supply after standard treatment. Class 3 would also be acceptable for urban supply, provided that the treatment for drinking water distribution - was advanced. Should the requirements be kept at the most stringent level, the treatment system will remain proscribed and the prospects of a territorially extensive depollution at a lower standard, indefinitely inhibited.

\subsection{Lessons learnt}

The three initiatives show innovative attempts to establish territorial and functional connections beyond the strict limits of their core purposes. But these attempts have been systematically constrained by regulatory and state practice fragmentation.

In the first initiative, intermediate targets regarding fields other than water management necessarily involves intergovernmental and intersectoral action from state and municipal branches. The correlation model establishing secure causal relationships between urban patterns and pollution is a basic step to facilitate this integration. In the settlements where integrated interventions were completed, overall robustness regarding floods, land sliding and building stability increased, as nearly all of the interventions included shoring up slopes and improving local drainage (Araújo et al. 2009; The World BANK 2004).

Regulatory fragmentation regarding municipal control of land use has to a large extent been offset by special licensing procedures based on the specific guidelines established by the Guarapiranga and Billings laws (SÃo PAulo 2006, 2009b). Likewise, the clear establishment of depollution targets in a relatively flexible regulatory framework for the basin area has given rise to a number of alternative supplementary solutions to be applied for local wastewater treatment, such as wetlands and other forms of direct treatment on water courses (Araújo et al. 2009; The World BanK 2004).

The problem with the regulatory system developed on water catchment areas is the scale of its jurisdiction. Since all these movements are aimed at each specific sub-metropolitan basin and respective basin laws, targets and controls locally debated under a flexible and performance oriented regulatory context turn into absolute parameters when formalized. Once established in each specific basin law, local depollution tar- 
gets become mandatory requirements enforced under rigid command and control surveillance. And this limits the integration potentialities regarding other scopes.

The second initiative involving flood control has, on the other hand, no problem with territorial jurisdiction. It is clearly stated within the state institutional framework that flood control must consider all the drainage basins flowing to the main water course as well as the hydraulic interconnections with neighboring basins, from a macro-metropolitan perspective. The problem with this system is the lack of intergovernmental and intersectoral integration. Municipal urban drainage initiatives and permissive land use often intensify undue discharges on already saturated receiving waters. One of the urgent needs is to improve real time flood control in the densely urbanized east-west metropolitan vector by augmenting diversion capacity southwards, along the Pinheiros river. But the strict environmental regulations on flow operation restrain the potential benefits of a cross-sector subsidization concerning improvement of pumping capacities. This has to do with the third initiative focussing on direct river depollution.

The financing of this direct depollution treatment system - a sequence of flotation and oxidation reactors along the river during inverted flow phases - was expected to be covered through increased electricity production of the Henry Borden plant. However, income from upping electricity production would not suffice to cover the extra costs of complementary treatment if full conformity with the quality standards established in the judicial settlement were to be attained. It appears that the water quality stipulations in this case were made with only the projected effects of dry season reversion and its discharge on the Billings reservoir in mind. They did not include the long term effects of urban upgrading (initiative 1) on reduction of loads originating in other areas. Although smaller in terms of water flow than the projected discharge of Pinheiros, these loads are much higher in terms of concentration. The settlement also appears to have disregarded the pollution loads flowing westwards and untreated towards the Medium Tietê Basin, pollution loads that would have been removed by the direct treatment of the diverted waters. Finally, they did not consider the removal of pollutants in wet season operation (flood control) because this is already part of existing protocols.

In short, the stringent command and control environmental regulation only paid attention to real time discharges to the target reservoir itself. It neither considered the macro-metropolitan benefits of absolute load removal from neighboring basins nor the cross-sector benefits of an enhanced reversion for flood control with attenuated diffuse pollution loads. This fragmentary view of environmental benefits reinforces the already fragmented regulatory and managing arrangements of each system considered. The need to reinforce pumping capacities of reversion for flood control involves huge investments pressuring an already squeezed and large - sector budget. Should it be considered in a broader prospect of cross-benefits and sharing costs with the direct depollution system on the river stream, it would be viable at a shorter term. However, to do so, the electricity generator responsible for the river quality improvement should be relieved from part of the quality requirements regarding direct treatment. This could possibly be compensated by intensifying the works of urban upgrading and sewage treatment on the catchment area - a prime responsibility of the water utility, with possible cross-subsidization from enhanced energy yields - under a macro-metropolitan perspective of cross-basin depollution. Altogether, a system like this would generate more net benefits in terms of water quality, urban upgrading, flood control and energy generation, to the whole macro-metropolitan bundle - neighboring basins included - than the sum of the net benefits of each of these initiatives. However, the immediate performance from the standpoint of each basin, locality or infrastructure mode, alone, tends to be lower than in the integrated context.

\section{Conclusions}

The main question to be raised, following the analysis of the three initiatives, is who - institutionally - should care about metropolitan and macro-metropolitan interests which extend local and sector agendas. Sector fragmentation of the infrastructure systems requires functional and territorial unbundling to ensure economic feasibility and separate accounting for each segment.

Environmental regulation is not fragmented this way. Rather, it applies to the combined results of multiple infrastructural initiatives in a given part of the environmental system. In the case of São Paulo, for example, water quality is organized according to specific areas of «environmental protection and development» (S̃̃o PAulo 1997), defined by the headwaters and tributaries to each metropolitan water catchment area. However, this organization according to rigid territorial fractioning makes it more difficult to take cross-basin benefits into consideration when targeting overall water quality improvement.

The results of these two fragmentary logics - sectoral and territorial - imply important constraints to integration and interconnection between networks form- 
ing the macro-metropolitan infrastructure bundle. Scale and scope complexities of the metropolitan and macro-metropolitan territories cannot be addressed under this prevailing fragmentary logic within regulation and state action. Even though not directly treated in this article, fragmentation also concerns socio-environmental movements. The positions of socio-environmental activists (WHATELY et al. 2008) normally raise important questions legitimated in the international agenda of sustainability. Similarly to the sector and environmental regulators, however, environmental activists tend to transfer global principles directly to local agendas, disregarding the metropolitan and macro-metropolitan scales in between.

\section{References}

Araújo, R.G., Pollachi, A., Yamazaki, D.R., BarCELlos, N.R., BRAGANÇA, R.M.P. \& Z. EsTERCI (2009): Relatório de planejamento estratégico. Programa Mananciais. - São Paulo: Secretaria de Saneamento e Energia, Coordenadoria de Saneamento.

Arisz, H. \& B.C. Burrell (2009): Urban drainage infrastructure planning and design considering climate change. - http:/www.periodicos.capes.gov.br/ 10.04.2011.

Barros, M.T.L. (2010): Relatório técnico sobre o desempenho do sistema Tietê - Pinheiros nos eventos chuvosos dos dias 08/12/2009 e 21/01/2010. - São Paulo: Escola Politécnica, Universidade de São Paulo. Barton, A.B., Smith, A.J., Maheepala, S. \& O. Barron (2009): Advancing IUWM through an understanding of the urban water balance. $18^{\text {th }}$ World IMACS MODSIM Congress, Cairns, Australia, 13-17 July 2009. - http://www.mssanz.org.au/modsim09/I9/barton.pdf 10.04.2011.

Braga, B.P.F., Porto, M.F.A. \& R.T. Silva (2006): Water management in metropolitan São Paulo. - In: Water Resources Management 22, 2: 337-352.

Conselho Nacional de Meio Ambiente - CONAMA (2005): Resolução CONAMA No. 357 de 17 de março de 2005. - http://www.cetesb.sp.gov.br/Agua/praias/ res_conama_357_05.pdf 18.08.2010.

DAI, T. \& J.W. LABADIE (2001): River basin network model for integrated water quantity/quality management. - In: Journal of Water Resources Planning and Management, September/October 2001:295-305.

Fundação Centro Tecnológico de Hidráulica FCTH (2009): Avaliação da qualidade das águas do sistema Pinheiros-Billings em função da operação do protótipo da flotação, Vol. 1. - São Paulo: FCTH.

Fundação de Apoio À Universidade de São Paulo FUSP (2002): Plano da bacia do Alto Tietê. Relatório final. - http://www.sigrh.sp.gov.br/sigrh/ARQS/RELATORIO/CRH/CBH-AT/559/irrigacao.pdf 04.10.2010. GrahaM, S. \& S. MARvin (2001): Splintering urbanism: networked infrastructures, technological mobilities and the urban condition. - London, New York: Routledge.

Graham, S. (2010): When infrastructures fail. - In: Graham, S. (ed.): Disrupted cities. When infrastructure fails. - New York: Routledge, e-book location: 153-933. Guy, S., Graham, S. \& S. Marvin (1997): Splintering networks: cities and technical networks in 1990s Britain. - In: Urban Studies 34, 2: 191-216.

HEANEY,J.P.,Pitt, R.\& R.FiELd (1999):Innovativeurban wet-weather flow management systems. - Cincinnati, $\mathrm{OH}$ : National Risk Management Research Laboratory, U.S. Environmental Protection Agency, http:/www. epa.gov/nrmrl/pubs/600r99029/600R99029prelim.pdf 20.01.2010.

Helm, D. \& T. Tindall (2009): The evolution of infrastructure and utility ownership and its implications. In: Oxford Review of Economic Policy 25, 3: 411-434. LAWRENCE, I. (2001): Integrated urban land \& water management. Planning and design guidelines. Technical Report 1/2001. - Canberra: Cooperative Research Centre for Freshwater Ecology, http://reshwater.canberra.edu.au/Publications.nsf/0/95214ed3c40105b2ca2 56f0f0014b12f/\$FILE/crc\%20final.pdf 26.07.2010.

Lindley, D.V. \& N.D. SingPuRWALla (2002): On exchangeable causal and cascading failures. - In: Statistical Science 17, 2:209-219.

LitTLE, R.G. (2010): Managing the risk of cascading failure in complex urban infrastructure. - In: GRAHAM, S. (ed.): Disrupted cities. When infrastructure fails. New York: Routledge, e-book location: 979-1334.

Martine, G. (2008): Global environmental change and the sustainable use of space in «second half» cities. In: UGEC Viewpoints No. 1, August 2008, http:/www. ugec.org 10.04.2011.

Norman, E., Bakker, K., Cook, C., Dunn, G. \& D.A. NoRman (2010): Water security: a primer. Fostering water security in Canada Project. - http://www.watergovernance.ca/wp-content/uploads/2010/04/WaterSecurityPrimer20101.pdf 10.04.2011.

O'Connor, T.P., Rodrigo, D. \& A. CAnnan (2010): Total water management: the new paradigm for urban water resources planning. - Conference Proceedings of the World Environmental and Water Resources Congress 2010 «Challenges of Change», Providence, Rhode Island, May 16-20, http:/ascelibrary.org/proceedings/ resource/2/ascecp/371/41114/335_1 10.04.2011.

Oliveira DE Jesus, J.A. (2006): Utilização de modelagem matemática 3D na gestão da qualidade da água em mananciais. Aplicação no reservatório Billings. Tese de doutoramento, http://www.teses.usp.br/teses/ disponiveis/6/6134/tde-17082006-174447/pt-br.php 26.07.2010.

Pagnoccheschi, B. (2000): A política nacional de recursos hídricos no cenário da integração das políticas públicas. - In: MuÑoz, H.R. (ed.): Interfaces da gestão de recursos hídricos. Desafios da Lei de Águas de 1997. - Brasília: Secretaria de Recursos Hídricos: 31-57. 
São Paulo (1997): Lei Estadual n 9.866, de 28 de novembro de 1997. Dispõe sobre diretrizes e normas para a proteção e recuperação das bacias hidrográficas dos mananciais de interesse regional do Estado de São Paulo. - http://www.sigam.ambiente.sp.gov.br/sigam2/ legisla \%C3\%A7\%C3\%A3o\%20ambiental/lei \%20 est\%201997_09866.pdf 04.10.2010.

São Paulo (2006): Lei ${ }^{\circ} 12.233$, de 16 de janeiro de 2006. Define a área de proteção e recuperação dos mananciais da bacia hidrográfica do Guarapiranga, e dá outras providências correlatas. - http://www.sigam. ambiente.sp.gov.br/sigam2/Repositorio/259/Documentos/12233.pdf 22.01.2007.

São Paulo (2009a): Lei n 13.579 , de 13 de julho de 2009. Define a área de proteção e recuperação dos mananciais da bacia hidrográfica do Reservatório Billings - APRM-B. - http:/www.al.sp.gov.br/legislacao/norma.do?id=156946 04.10.2010.

São Paulo (2009b): Controle de inundações na região metropolitana de São Paulo. Ações do governo do estado (nota técnica). - São Paulo: Secretaria de Saneamento e Energia: 1-16.

SÃo Paulo (2010): Termos de referência para a elaboração do terceiro plano diretor de macrodrenagem da bacia do Alto Tietê. - São Paulo: Secretaria de Saneamento e Energia: 1-20.

Sharan, Y., Coccossis, H. \& A. TAL (eds) (2007): Water supply in emergency situations. NATO security through science series $\mathrm{C}$ : environmental security. New York: Springer-Verlag.

Silva, R.T. \& M.F.A. Porto (2003): Gestão urbana e gestão das águas: caminhos da integração. - In: Estudos Avançados 17, 47: 129-145.

SILVA, R.T. (2000): The connectivity of infrastructure networks and the urban space of São Paulo in the 1990s. - In: International Journal of Urban and Regional Research 24, 1: 139-164.

The World Bank (2004): Report No: 28962. Implementation completion report (CPL-35030 CPL-35040 CPL-35050) on a loan in the amount of US $\$ 245$ million equivalent to the states of São Paulo and Paraná and for the Federal State of Brazil for the Water Quality \& Pollution Project. June 25, 2004. (Public Disclosure Authorized). - http://www-wds.worldbank.org/ servlet/WDSContentServer/WDSP/IB/2004/07/02/00 0012009_20040702125122/Rendered/PDF/28962.pdf 04.10 .2010 .

Whately, M., Santoro, P.F., Ferrara, L.N. \& F.B. BAJESTEIRo (eds) (2008): Mananciais: uma nova realidade? - São Paulo: Instituto Socioambiental, http:// www.unep.org.br/admin/publicacoes/texto/Mananciais_uma_nova_realidade.pdf 04.10.2010.

Zevenbergen, C., Veerbeek, W., Gersonius, B. \& S. VAN HERK (2008): Challenges in urban flood management: travelling across spatial and temporal scales. - In: Journal of Flood Risk Management 1, 2: $81-88$.

\section{Summary: Integration of hydraulic infrastructure in metropolitan São Paulo. Prospects of change in a context of growing vulnerability}

This article discusses the prospects of change of policy, planning, design and operation of the metropolitan water resources and hydraulic infrastructure in São Paulo. Three initiatives are analyzed in terms of their potential to simultaneously address chronic socio-environmental vulnerability and disaster risks. The initiatives include the protection of metropolitan reservoirs and headwaters; flood control strategy in face of environmental change; and the depollution project for the southern metropolitan hydro-energetic complex, combining flood control, water depollution, urban upgrading and energy safety. Evidence from these initiatives shows infrastructure fragmentation to be a major cause of vulnerability. Planning practices need to be further adapted to better reflect the integrative demands of working at macro-metropolitan and cross sector scopes in order to be able to address the complexities of the current infrastructural bundle, a developmental direction that requires deep reshaping of regulatory frameworks and state practices.

Keywords: hydraulic infrastructure, integrated urban water management, vulnerability, regulatory fragmentation, metropolitan complexity Résumé: Intégration des infrastructures hydrauliques
dans la région métropolitaine de São Paulo. Perspec-
tives de changement dans un scénario de vulnérabilité
croissante
Cet article examine les perspectives de changement sur la politique, la planification, la conception et l'exploitation des ressources en eau et des infrastructures hydrauliques métropolitaines de São Paulo. Trois initiatives métropolitaines sont analysées relativement à leurs potentialités de faire face simultanément à la vulnérabilité socio-environnementale chronique et aux risques de désastre. Elles concernent la protection des réservoirs métropolitains et des eaux d'amont, la stratégie de contrôle des inondations liée aux changements environnementaux et la stratégie de dépollution du complexe hydro-énergétique situé au sud de São Paulo, en combinant contrôle des inondations, dépollution de l'eau, amélioration urbaine et sécurité énergétique. L'étude de ces initiatives montre que la fragmentation des infrastructures est une cause majeure de vulnérabilité. Il paraît ainsi nécessaire d'améliorer les pratiques de planification intégrées à l'échelle macro-métropolitaine et les fonctions transversales pour faire face à la complexité de l'ensemble de l'infrastructure. Cela exige un profond remodelage des cadres réglementaires et des pratiques de l'État.

Mots-clés: infrastructure hydraulique, gestion intégrée 
de l'eau en milieu urbain, vulnérabilité, fragmentation en matière de régulation, complexité à l'échelle métropolitaine

\section{Zusammenfassung: Wasserversorgungsinfrastruktur im Metropolraum São Paulo. Perspektiven des Wandels im Kontext zunehmender Vulnerabilität}

Dieser Artikel diskutiert die Politik, die Planung, das Design und den Betrieb der metropolitanen Wasserressourcen und -versorgungsstrukturen von São Paulo aus einer Perspektive des Wandels. Es werden drei Initiativen analysiert und es wird eingeschätzt, welches Potential diese Initiativen besitzen, sowohl die in São Paulo existierende chronische soziale und umweltliche Vulnerabilität, als auch mögliche unvorhergesehene Katastrophen zu adressieren. Die analysierten Initiativen beziehen sich auf den Schutz der Oberläufe und Speicherbecken, die Hochwasserschutzstrategie und die Sanierung des Wasser-Energie-Komplexes im Süden von São Paulo, welche Massnahmen zum Hochwasserschutz, zur Wasserqualität, zur Stadterneuerung und zur Energieversorgungssicherheit kombiniert. Die Diskussion und Analyse der Initiativen ergab, dass die Infrastrukturfragmentierung in São Paulo eine Hauptursache für Vulnerabilitäten darstellt.

Schlüsselwörter: hydraulische Infrastruktur, integriertes städtisches Wassermanagement, Verwundbarkeit, reguläre Fragmentierung, metropolitane Komplexität

Prof. Dr. Ricardo Toledo Silva, Faculty of Architecture and Urbanism, University of São Paulo, Rua do Lago 876,05508-080 São Paulo, Brazil.

e-mail: ritsilva@usp.br

\section{Manuskripteingang/received/manuscrit reçu le} 3.1.2011

Annahme zum Druck/accepted for publication/accepté pour publication: 26.6 .2011 